\title{
Effects of Land Use Change on Land Degradation Reflected by Soil Properties along Mara River, Kenya and Tanzania
}

\author{
Ally-Said Matano1,2, Canisius K. Kanangire1, Douglas N. Anyona², Paul 0. Abuom², \\ Frank B. Gelder ${ }^{3}$, Gabriel O. Dida ${ }^{4 *}$, Philip 0. Owuor ${ }^{5}$, Ayub V. O. Ofulla ${ }^{4}$ \\ ${ }^{1}$ Lake Victoria Basin Commission Secretariat, Kisumu, Kenya \\ ${ }^{2}$ School of Environment and Earth Sciences, Maseno University, Maseno, Kenya \\ ${ }^{3}$ Probe International, Inc., Auckland, New Zealand \\ ${ }^{4}$ School of Public Health and Community Development, Maseno University, Maseno, Kenya \\ ${ }^{5}$ Department of Chemistry, Maseno University, Maseno, Kenya \\ Email: ${ }^{*}$ gdidah@gmail.com
}

Received 2 November 2014; accepted 18 November 2014; published 13 January 2015

Copyright (C) 2015 by authors and Scientific Research Publishing Inc.

This work is licensed under the Creative Commons Attribution International License (CC BY). http://creativecommons.org/licenses/by/4.0/

(c) ()

\section{Abstract}

Human-induced changes to natural landscapes have been identified as some of the greatest threats to freshwater resources. The change from natural forest cover to agricultural and pastoral activities is rampant especially in the upper Mara River catchment (water tower), as well as along the course of the Mara River. The objective of this study was to determine the effect of land use change on the physico-chemical properties of soil (bulk density, carbon, nitrogen, phosphorus and $\mathrm{pH}$ ) along the course of the Mara River. Five major land uses (agricultural lands, livestock/pastoral lands, forested lands, conservancy/game reserves, and natural wetland) were explored. Results revealed that the mean soil bulk density was $0.956 \mathrm{~g} / \mathrm{cm}^{3}$ and differed significantly between sites ( $p$ < 0.001). Live biomass values differed significantly between sampling sites (land use types) within the Mara River Basin $\left(F_{(4,147)}=8.57, p<0.001\right)$. The mean infiltration over a period of 150 minutes differed, not only among sampling sites, but also between different sides of the river (left and right) within the same sampling site. Soil $\mathrm{pH}$ was generally acidic across the five sites and varied significantly $\left(F_{(4,63)}=19.26, p<0.0001\right)$ between sites along the Mara River Basin. The mean percentage soil nitrogen across all sampling blocks was $4.87 \%$, with significant differences observed in percentage soil nitrogen $\left(F_{(4,63)}=3.26, p<0.006\right)$ between sampling sites. The results indicated that the five land use types affected land degradation differently along the Mara River, while adjacent land degradation affected water physico-chemical properties. These results point to the need to have focused policies on integrated land and water resource management strategies in the Mara River Basin.

\footnotetext{
${ }^{*}$ Corresponding author.
} 


\section{Keywords}

\section{Catchment Area, land Degradation, Land Use Types, Mara River, Riparian Land}

\section{Introduction}

Land use and land cover changes associated with human activities and natural factors compromise many ecosystems including watersheds of important rivers [1]. Land degradation resulting from human activities has been a major global challenge since the 20th century and will remain high on the international agenda in the 21st century [2]. According to Bai et al. [3], land degradation is increasing in severity and extent in many parts of the world, with more than $20 \%$ of all cultivated areas, $30 \%$ of forests and $10 \%$ of grasslands undergoing degradation. In recent centuries, an increasing amount of riparian lands have been developed and utilized for agriculture, human settlements and development of cities and towns [4]. This has significantly impacted on critical catchment areas, thus altering water quality in aquatic ecosystems.

Land degradation encompasses the whole environment including individual factors such as soils, water resources (surface and ground), forests (woodlands), grasslands (rangelands), croplands (rainfed and irrigated) and biodiversity (animals, vegetative cover and soil) [5]. Different studies have examined the effects of land use/ cover change on soil physico-chemical properties, and most concur that despite its consequences vary, land use change frequently leads to nutrient losses and reduction of organic matter inputs in the soil [6]-[8]. Conversion of natural forest to other forms of land uses such as farmlands and pasturelands can provoke soil erosion and lead to a reduction in soil nutrients and modification of soil structure [9]. Rai and Sharma [10] also concur that change in land use types negatively affects soil productivity characteristics such as soil bulk density and hydraulic conductivity. Cultivation of forests for instance can diminish soil carbon (C) within a few years of initial conversion [11] and substantially lower mineralizable nitrogen (N) [12]. Islam and Weil [13] reported an increase in bulk density and a reduction in porosity and aggregate stability following the conversion of forest land to crop land, with consequent degradation of adjacent aquatic system.

Soil erosion, salinity and absence of vegetation cover are early warning signs of land degradation, which are likely to influence adjacent aquatic systems through sediment loading. The relationship between land use and water quality has also been demonstrated over the last two decades [14] [15]. There is convincing evidence that watersheds dominated by agriculture and/or human settlement have significantly higher river and nutrient levels [15] [16]. Since rivers provide many ecological and social service functions, they are subject to increased human exploitation and pollution [17]. A river system degrades under severe interference by anthropogenic activities in the catchment [4]. Interference can either occur directly on the river itself or indirectly by degradation of adjacent riparian land which then impacts on the aquatic system. Numerous studies have demonstrated the effects of land use change on erosion and sediment loading patterns in aquatic ecosystems (Alin et al. [18]). The spatial relationship between land use and water quality has also been examined by many researchers (Tong and Chen [19], Ngoye and Machiwa [20] and King et al. [21]). More specifically, some investigators have compared land cover within certain distances from a stream or sampling site [22]. Burcher et al. [1] also observed that changes in land use and land cover interact with anthropogenic and natural drivers to impact negatively on the water quality of watersheds.

Three important spatial scales that influence physical, chemical and biological conditions in a river are basin-wide conditions, riparian (area adjacent to the stream) conditions, and in-stream conditions. The impact of land use change on the watershed environment has also been reported to vary across different spatial scales [23]. Land use changes therefore have both direct and indirect effects on freshwater ecosystems with the former having immediate ecological impacts (e.g. destruction of wildlife habitats), while the latter has impacts that are normally transmitted via altered flow or sediment transport patterns (e.g. lower productivity due to increasing turbidity). Sediment deposition in adjacent water bodies is driven by soil erosion, which is the most widely recognized and most common form of land degradation. Overgrazing of rangelands, poor cultivation of croplands, deforestation and urbanization are some of the land use practices that result in increased soil erosion and subsequent load of sediments and nutrients into aquatic systems [24].

Land use changes in the Lake Victoria Basin have transformed land cover to mainly farmlands, grazing lands, human settlements and urban centres from the previous natural vegetation cover [9]. Over the last 50 years, the 
Mara River basin has undergone major changes in land use and land cover. Forests and savannah grasslands have been cleared and turned into land with the main purpose of expanding agricultural activities [25]. Many researchers, including Mugisha [26], Misana et al. [27] and Olson et al. [28], all concur that most of the changes observed in land use/cover in many parts of Africa are mainly associated with extension and intensification of agricultural activities to new areas. Livestock and wildlife grazing has also been cited as a source of soil degradation. Over cultivation and overgrazing have been linked to increased nutrient transfer and bulk density through nutrient loss and compaction of the soil leading to accelerated soil erosion [29]. High soil bulk density has been a serious land degradation problem in the entire Lake Victoria basin landscape including the Mara River Basin, due to unsustainable land uses [30]. Over the last 50 years, the Mara River Basin has undergone unprecedented changes in land use, just like many other river basins within the larger Lake Victoria Basin (LVB). Accelerated loss of vegetation at the upper Mara River basin has been reported in several studies, including Mati et al. [31] and WWF [32].

The Mara River Basin (MRB) plays a major ecological and socio-economic role in communities living in the basin. There is growing evidence of land degradation in the MRB due to improper land use practices, which directly impacts on adjacent aquatic ecosystems. According to Dwasi [25], forests and savannah grasslands in MRB have been cleared and turned into agricultural lands. Rapidly increasing population in the Mara River Basin puts an even greater pressure on the limited natural resources, resulting in increased pollution. Records from the Government of Kenya [33] indicate that over 7000 hectares of Mau forest, which is one of the major water towers in Kenya, were destroyed between 2000 and 2003. The records further show that the area under cultivation in the Amala sub catchment increased from less than $20 \%$ in 1960 to more than $51 \%$ in 1991 to give way to Olenguruone Settlement Scheme. Such changes in land use result in increased degradation of water quality, thus affecting aquatic biota (flora and fauna). The Lake Victoria Basin region has witnessed increased land use changes in recent times, some of which have led to accelerated land degradation reflected through diminishing vegetation cover, reduced biomass, increased bulk density, and reduced soil nutrients among others [31] [33]. A recent study by USAID EA [34] also linked land use practices in the Mara River Basin to environmental flows and water quality degradation along the Mara River. Over time, the Mara River Basin has witnessed intensified land use changes resulting in increased pollution of the Mara River waters, visible through the high turbidity, total dissolved and total suspended solids, which is an indication of off-site effects of soil erosion. This has resulted in changes in the physical, chemical and biological properties of water in the Mara River ecosystem. However, the exact link between land use types and soil properties along the Mara River Basin has not been well established. This study therefore set out to determine the effects of land use types on land degradation as reflected by soil properties (soil bulk density, soil organic carbon, nitrogen, and phosphorus) along the Mara River.

\section{Materials and Methods}

\subsection{Study Area Description}

The Mara River basin covers $13,750 \mathrm{~km}^{2}$ and lies between Kenya and Tanzania. The Basin is located roughly between longitudes $33^{\circ} 47^{\prime} \mathrm{E}$ and $35^{\circ} 47^{\prime} \mathrm{E}$ and latitudes $0^{\circ} 38^{\prime} \mathrm{S}$ and $1^{\circ} 52^{\prime} \mathrm{S}$, with the upper $65 \%$ area $\left(8941 \mathrm{~km}^{2}\right)$ being in Kenya and the remaining 35\% in Tanzania (Figure 1). The Mara River originates from the Napuiyapui swamp in the Mau escarpment in the highlands of Kenya, with altitudes ranging from $2932 \mathrm{~m}$ at its source to $1134 \mathrm{~m}$ at Musoma bay.

Rainfall varies inter-annually by a factor of about four between extreme wet and dry years [35]. The river which has for a long time been considered as one of the more pristine rivers draining into Lake Victoria [36], traverses through different land use types including forests, farmlands, open lands, urban centers, game reserves and conservancy before flowing through the Mara Swamp at Musoma Bay in the lower Mara and finally into Lake Victoria. Five distinct land use types along the Mara River were selected for this study. These were: Silibwet sampling site (forested land but with some human interference), Kapkimolwa (agropastoralism with subsistence and large scale farming), Bomet town sampling site (urban set-up with high population and economic activities), Ngerende sampling site (protected area/conservancy) and Kirumi bridge sampling site (a natural wetland with relatively low human interference).

\subsection{Study Design Based on Land Degradation Surveillance Framework (LDSF)}

A modified version of the LDSF was used in this study. The cross sectional field component of this study was 


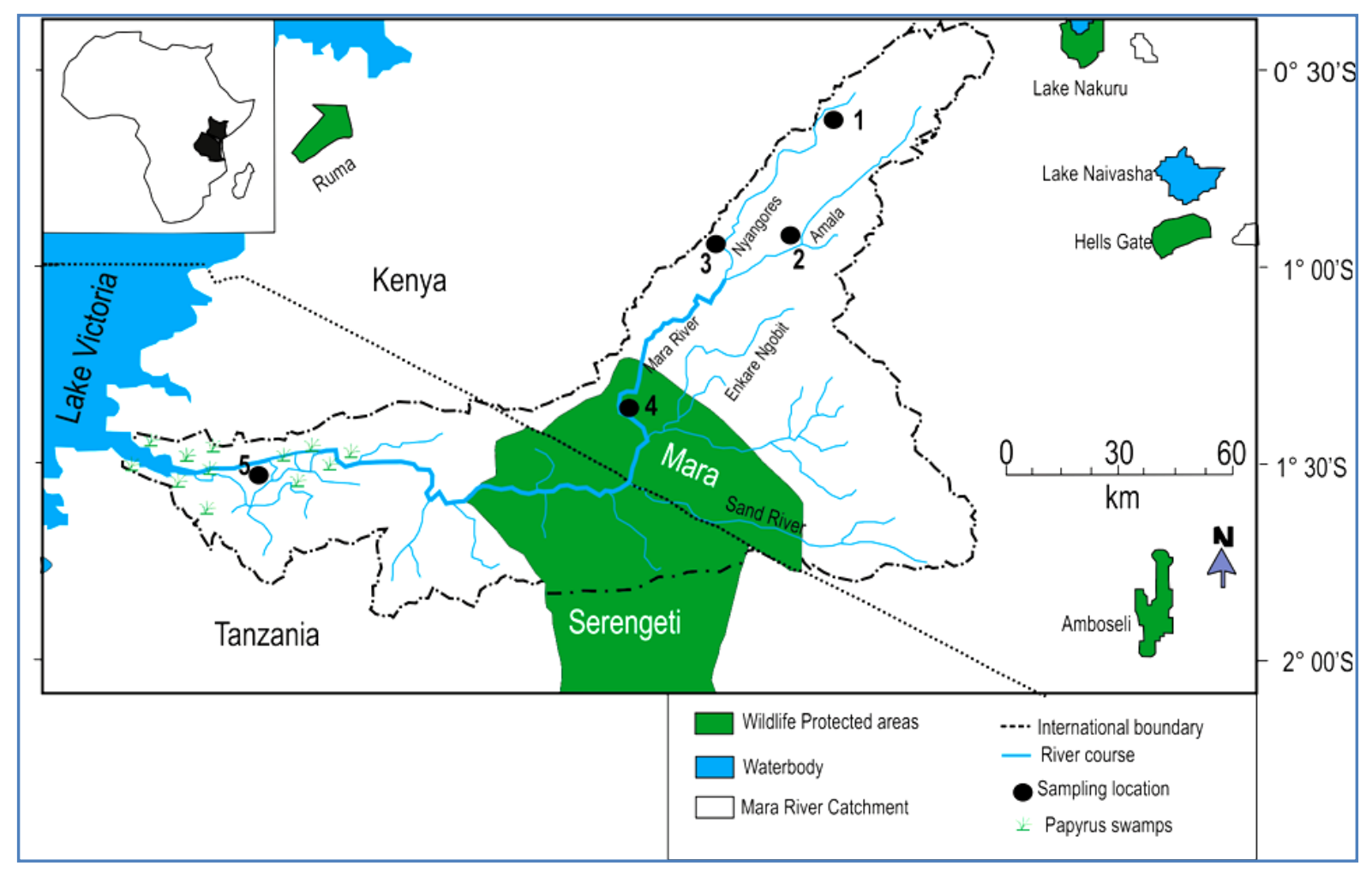

Figure 1. Map of the Mara River basin showing sampling blocks numbered 1 - 5.

carried out between July 2011 and September 2011 during which soil samples were collected for analysis in established laboratories at the International Centre for Research in Agroforestry (ICRAF), Kisumu, Kenya and the Kenya Forestry Research Institute (KEFRI) in Maseno, Kenya. In the study, the entire Mara River Basin represented a block with 5 sampling sites, namely, Silibwet, Kapkimolwa, Bomet, Ngerende and Kirumi, and purposively selected to represent different predominant land uses. In each of the sampling sites there were 8 plots (four on each side of the river) which were laid on a line transect on either side of the river. Each sampling site was also projected to within a $5 \mathrm{~km}$ radius from a designated central point within the river, out of which 4 plots were selected within an area lying between $22.5^{\circ}$ and $45^{\circ}$ degrees on either side of the river. The left and right sides of the river were determined with the researcher facing downstream (Figure 2).

Thereafter, each of these sites was laid out as a straight-line transect, with sampling distances for the 4 plots doubling from the central point up to a maximum of the $5 \mathrm{~km}$ limit. The same was repeated on the other side of the river. For instance a $3 \mathrm{~km}$ transect had the first plot (L1 or R1) $200 \mathrm{~m}$ from the central point, with the second (L2 or R2) being located $400 \mathrm{~m}$ from the first plot (600 m from the central point) and the third $800 \mathrm{~m}$ from the second plot (1.4 km from the central point). The final plot in such transect (L4 or R4) was $1.6 \mathrm{~km}$ from the third plot, and thus $3 \mathrm{~km}$ from the water sampling point. In all cases the sampling point was located at a bridge.

Infiltration rates were determined in situ at each sampling point, while soil samples were collected for determination of soil bulk density, soil carbon, $\%$ soil nitrogen, $\%$ soil phosphorus and soil $\mathrm{pH}$ in the laboratory. A total of 16 soil samples, 8 from the left and 8 from the right side of the river at each sampling site were collected making a total of 80 samples for soil $\mathrm{pH}$, soil carbon, and percentage nitrogen and phosphorus determination. Modifications aside, all other LDSF protocols were observed.

\subsection{Land Degradation Surveillance Framework Sampling Plan}

In this study, plots measuring $1000 \mathrm{~m}^{2}, 4$ subplots (SP) measuring $100 \mathrm{~m}^{2}$ (Figure 3) and their equidistance were established from each of the 5 sampling sites. Each subplot yielded at least 1 top-soil $(0-20 \mathrm{~cm})$ and 1 sub-soil $(20-50 \mathrm{~cm})$ aggregate samples (yielding at least 8 soil sample replicates per plot). Bulk Density (BD) sample collection was done at SP 1 (centre) using a standard Bulk Density (BD) ring, and weight readings were 


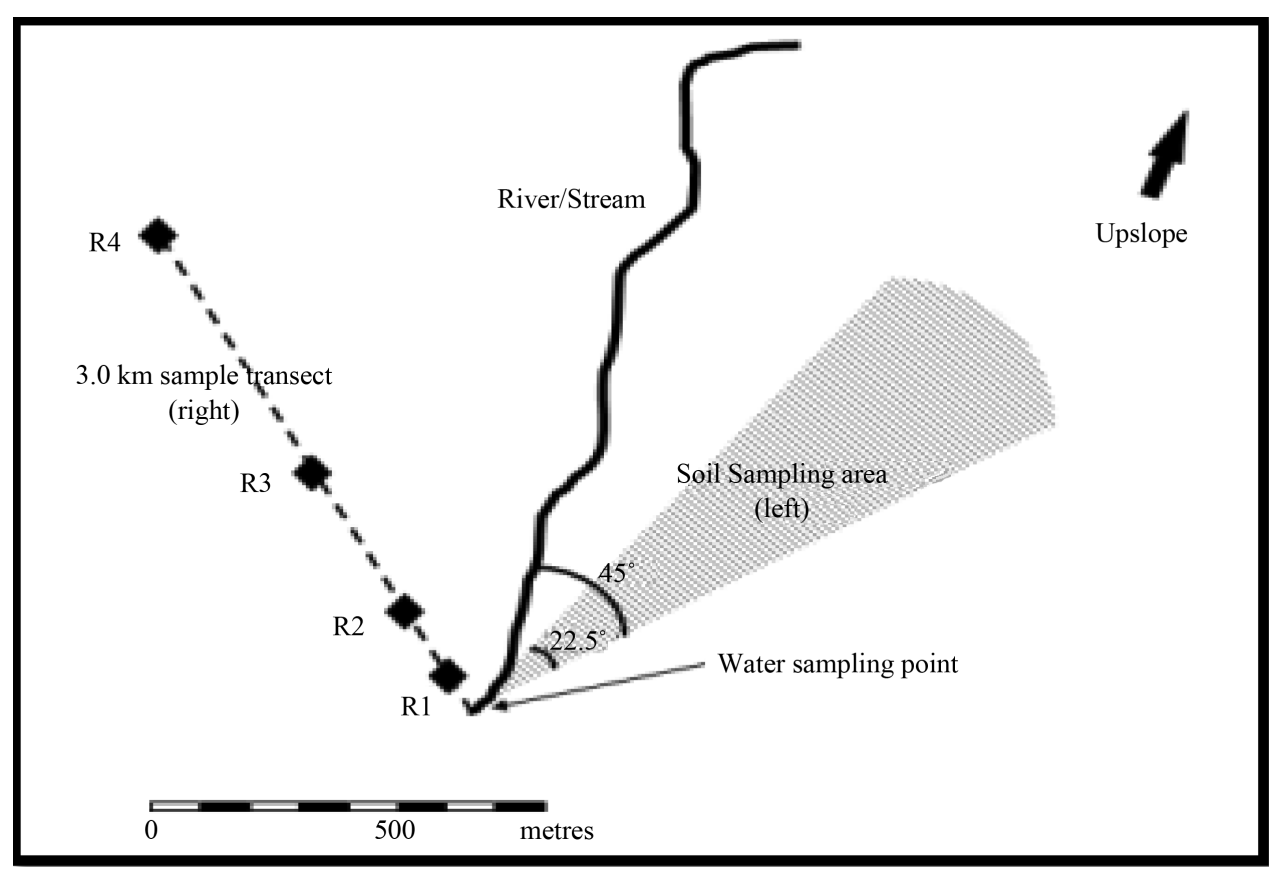

Figure 2. Sampling plot within a sampling site.

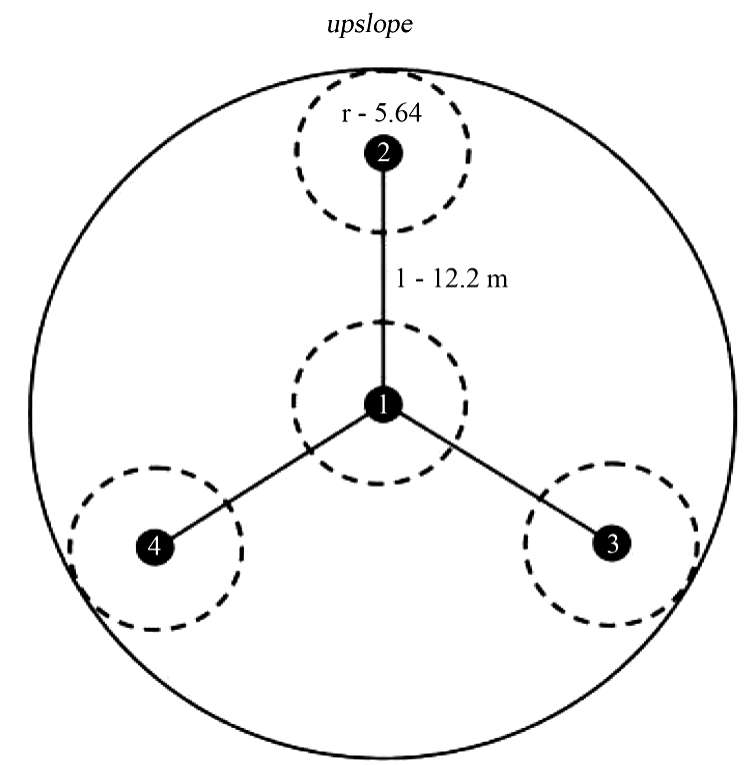

Figure 3. A $1000 \mathrm{~m}^{2} \mathrm{LSDF}$ plot layout showing the four $100 \mathrm{~m}^{2}$ sub-plots and distances.

determined on-site. In addition, soil hydraulic conductivity tests (infiltration) were carried out at SP 1 (center) in 8 plots within the sampling site thus providing data for 40 soil conductivity samples.

\subsection{Soil Sampling for Land Degradation Analysis}

Soil sampling was done on both sides of the river within the area lying between the bearings of $22^{\circ}-45^{\circ}$ upstream from the water sampling site as depicted in Figure 2 (R1 to R4 and L1 to L4). Soil samples for the soil $\mathrm{pH}$, soil organic carbon (SOC), soil nitrogen, soil phosphorus, and soil bulk density were collected from the river catchment sites using a Dutch auger. Care was taken to avoid mixing the top and sub soil samples, and also to avoid collapsing the hole during sampling. As such, augering was done by taking small and steady bites and by 
keeping the auger as vertical as possible. Once a significant amount of soil was collected, it was emptied into a suitably labeled bucket to avoid overfilling the auger. In each site, 4 plots of $1000 \mathrm{~m}^{2}$ were identified systematically. From each plot four sub plots were identified from which top soil $(0-20 \mathrm{~cm})$ and subsoil $(20-50 \mathrm{~cm})$ were collected giving 8 different soil samples replicates (4 topsoil and 4 subsoil samples) packed in 8 different polythene bags sealed with rubber band for laboratory analysis at the Kenya Forestry Research Institute (KEFRI) laboratory at Maseno, Kenya. Each polythene bag was clearly labeled with catchment name, area, plot, position and depth.

\subsection{Soil Sampling for Land Degradation Analysis}

Soil samples for determining soil nitrogen and soil phosphorous were air dried by spreading the sample out as a thin layer into shallow trays. Maximum care was taken to ensure that no materials from the sample were lost or discarded. Drying time depended on the condition of samples and ambient conditions, but they were nevertheless dried thoroughly. The choice for air dried samples was preferred because of the convenience in handling as well as to reduce variation due to moisture [37]. The air dried samples were then ground gently with a wooden pestle and mortar and pressed through a $2 \mathrm{~mm}$ sieve [38]. In line with Ben-Dor and Banin [37], the screened sample was subjected to reflectance spectrometer which provided non-destructive rapid prediction of soil physical, chemical and biological properties in the laboratory at KEFRI, Maseno, Kenya.

\subsection{Determination of Soil Bulk Density}

Bulk Density (BD) samples were collected at each of Sub-Plot 1 using a standard Bulk Density (BD) ring. This involved a cylindrical metal sampler $(52 \mathrm{~mm}$ high and $51 \mathrm{~mm}$ diameter) being driven into the soil until at the same level with ground. The sample was removed by digging around the ring with the trowel underneath it to prevent any loss of soil. Excess soil from the sample was removed with a flat bladed knife and the bottom of the sample made flat and even with the edges of the ring.

The total sample was put into a polythene bag for laboratory analysis and sealed with rubber band. Each polythene bag was identified by the sample site identification code. Top soil bulk density was used to characterize differences in soil compaction among different land use types in the landscape. A total of 32 soil sample replicates were collected per cluster ( 1 top soil sample $\times 4$ sub-plots $\times 4$ plots $\times 2$ sides of the river) during the field work. Coarse organic matters were removed manually from bulk density soil samples. In the laboratory at International Centre for Research in Agroforestry (ICRAF), Kisumu, Kenya, the samples were oven dried completely at $105^{\circ} \mathrm{C}$, weighed on sensitive weighing machine, and weight recorded in grams. The bulk density was then calculated based on mass/volume ratio of the bulk density sampling ring and values recorded.

\subsection{Determination of Soil Infiltration Rate}

All infiltration measurements were carried out at the mid sub-plots (SP 1) along the sampling transects. Eight (8) measurements were made per sampling site ( 1 mid subplot $\times 4$ plots $\times 2$ sides of the river). Surface saturated hydraulic conductivity was measured using single-ring cylinder, $16 \mathrm{~cm}$ inner diameter according to Reynolds and Elrick [39] taking into account ring radius, depth of ring insertion and depth of ponding. The test calculations were based on shape factors that suggest that field saturated hydraulic conductivity could be obtained with accuracy of about $\pm 20 \%$ [39]. The ring was driven into a pre-wetted soil surface according to procedure reported by Reynolds and Elrick [39]. The ring was then filled with water up to a given initial depth and the initial water depth noted while a given time interval (in minutes) was set.

At each and every interval the water depth was noted and the ring refilled to the initial depth. Using a stopwatch, readings were taken first, at 5 minute intervals (where possible) for at least the first 30 minutes, then the interval were increased to 10 minutes ( 1 hour), and finally to 20 minutes ( 1 hour or until the readings had stabilized). After two and half to three hours of ponding water in the ring, steady infiltration $\left(Q_{s}\right.$, in $\mathrm{mm}$ per hour) and steady ponding depth $(W$, in $\mathrm{cm})$, the depth of ring insertion $(d$ in $\mathrm{cm})$, was recorded for the ring. The determination of field saturated hydraulic conductivity was based on mass balance equation of flow into soil. Using mass balance, the steady infiltration from a single ring $\left(Q_{s}\right)$ in $\mathrm{mm} / \mathrm{hr}$ was approximated by the formula: $Q_{s}=Q_{p}+Q_{g}$, where $Q_{p}$ and $Q_{g}$ are the steady water out flows from the ring due to hydrostatic and capillary pressure, and due to gravity, respectively. 


\section{Statistical Methods}

The field data was first entered in to Excel spreadsheet and analyzed for descriptive statistics. Further analysis was done using various statistical packages, including Genstat and the Statistical Package for Social Sciences (SPSS) software version 11.0. One way analysis of variance (ANOVA) was performed to test for significant differences among different soil and water quality parameters in relation to the five different land use types along the Mara River. If the main effects were found to be significant at $p<0.05$, a post hoc separation of means analysis was done by means of Duncan Multiple Range Test (DMRT) to further elucidate the specific differences, while correlations/regression and principal component analysis (PCA) were employed to establish the inter-relationships between and within land and water based variables.

\section{Results}

Five distinct land use types were identified along the Mara River based on their dominant land uses and characteristics. These were roughly forested but with human interference, agro-pastoralism, urban setting, protected/ conservancy area and natural wetland. The link between degradation and its effect on land use is central to nearly all published definitions of land degradation. In the current study, several soil physical properties were measured including soil bulk density, soil infiltration rates among others.

\subsection{Soil Texture and Soil Particle Size Grades}

Four different soil texture particles, namely, clay (C), sandy loam (SL), sandy clay loam (SCL) and silt clay (SC), were recorded. The current results show a decreasing trend in the proportion of clays towards the lower Mara. Proportions of sandy loam and sandy clay loam, which were negligible in the upper Mara River basin were clearly manifested at Ngerende towards the lower parts of the Mara River basin. All soil samples from Silibwet and Bomet sites showed higher properties of pure clay (C) particles, while soils from Kapkimolwa and Ngerende sampling sites recorded $3 \%$ and $24 \%$ of silt and clay, respectively. On the contrary, soils from Kirumi sampling site had higher proportions of sandy clay loam, followed by sandy loam.

\subsection{Land Degradation Based on Soil Infiltration Rates}

The mean infiltration over a period of 150 minutes differed, not only among sampling sites but also between different sides of the river (left and right) within the same sampling site. For instance, while mean infiltration rate on the left side of the river at Silibwet sampling site was $22.6 \mathrm{~mm} / \mathrm{hr}$ that recorded on the right side was $16.2 \mathrm{~mm} / \mathrm{hr}$. The highest infiltration rate of $66.7 \mathrm{~cm} / \mathrm{h}$ was recorded on the left side of the river at Bomet sampling site and lowest $1.2 \mathrm{~mm} / \mathrm{hr}$ ) on the left side of the river at Ngerende sampling site (Figure 4).

\subsection{Land Degradation Based on Live Biomass Levels at Different Sampling Sites}

Live biomass values differed significantly between sampling sites (land use types) within the Mara River basin

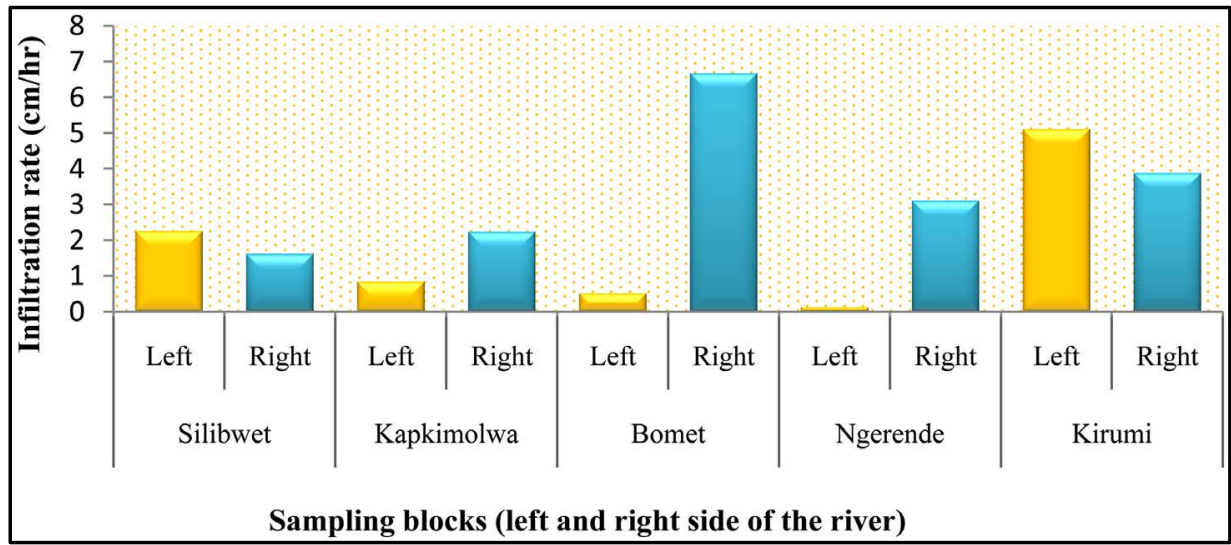

Figure 4. Infiltration rates on the right and left sides of the river per site. 
(one-way ANOVA, $\mathrm{F}_{(4,147)}=8.57, \mathrm{p}<0.001$ ). Duncan Multiple Range Test (DMRT) further established that live biomass at Kirumi sampling site was significantly higher compared to all the other sites. Live biomass at Silibwet, Kapkimolwa and Bomet sampling sites did not however show any significant variation between them. Likewise, live biomass recorded at Bomet sampling site was not significantly different from that recorded at Ngerende, Silibwet and Kapkimolwa sampling sites. In addition, live biomass values recorded on the left and right sides of the river at all the sampling sites were different, with some sampling sites having higher values on one side of the river than others, as shown in Table 1.

\subsection{Land Degradation Based on Soil Chemical Properties Due to Land Use Changes}

\section{Soil pH Levels}

Soil $\mathrm{pH}$ was generally acidic across the five sites and varied significantly (One-way ANOVA, $\mathrm{F}_{(4,63)}=19.26, \mathrm{p}<$ 0.0001) between sites along the Mara Basin (Table 2). Duncan Multiple Range Test (DMRT) further established that soil $\mathrm{pH}$ levels at Silibwet and Bomet sampling sites differed significantly from the other three sites and among themselves. Lowest soil $\mathrm{pH}$ levels $(5.53 \pm 0.43)$ were recorded at Silibwet sampling site and highest $(6.85 \pm 0.33)$ at Ngerende sampling site (Figure 5).

\subsection{Percentage Soil Nitrogen and Phosphorus Levels}

The mean percentage soil nitrogen across all sampling blocks was $4.87 \%$, with significant differences observed in percentage soil nitrogen (ANOVA, $\mathrm{F}_{(4,63)}=3.26, \mathrm{p}<0.006$ ) between sampling sites (Table 2). DMRT

Table 1. Live biomass levels recorded on the left and right sides of the river.

\begin{tabular}{|c|c|c|c|}
\hline Sampling Sites & Side of River & Live Biomass $\left(\mathrm{g} / \mathrm{m}^{2}\right)$ & Overall Mean $\left(\mathrm{g} / \mathrm{m}^{2}\right)$ \\
\hline \multirow{2}{*}{ Silibwet } & Left & 22.63 & \multirow{2}{*}{$17.14^{\mathrm{BC}}$} \\
\hline & Right & 11.65 & \\
\hline \multirow[b]{2}{*}{ Kapkimolwa } & Left & 20.35 & \multirow{2}{*}{$21.83^{\mathrm{B}}$} \\
\hline & Right & 23.33 & \\
\hline \multirow[b]{2}{*}{ Bomet } & Left & 19.63 & \multirow[b]{2}{*}{$22.96^{\mathrm{B}}$} \\
\hline & Right & 26.29 & \\
\hline \multirow{2}{*}{ Ngerende } & Left & 10.48 & \multirow{2}{*}{$10.32^{\mathrm{C}}$} \\
\hline & Right & 10.16 & \\
\hline \multirow{2}{*}{ Kirumi } & Left & 93.14 & \multirow{2}{*}{$75.44^{\mathrm{A}}$} \\
\hline & Right & 57.73 & \\
\hline
\end{tabular}

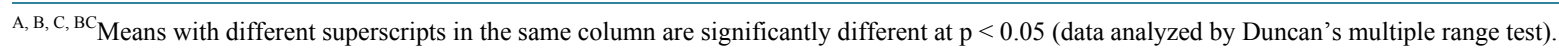

Table 2. Mean $( \pm \mathrm{SD})$ soil parameters at different sampling blocks along Mara River.

\begin{tabular}{|c|c|c|c|c|c|}
\hline Sampling Blocks & Soil Bulk Density $\mathrm{g} / \mathrm{cm}^{3}$ & Live Biomass & Soil pH & \% Soil Phosphorus & \% Soil Nitrogen \\
\hline Silibwet & $0.867 \pm 0.12^{\mathrm{C}}$ & $22.96 \pm 6.79^{\mathrm{B}}$ & $5.53 \pm 0.43^{C}$ & $1.24 \pm 0.72^{\mathrm{B}}$ & $2.07 \pm 2.20^{\mathrm{C}}$ \\
\hline Kapkimolwa & $0.938 \pm 0.10^{\mathrm{BC}}$ & $21.83 \pm 10.41^{\mathrm{B}}$ & $6.55 \pm 0.26^{\mathrm{A}}$ & $1.58 \pm 0.52^{\mathrm{B}}$ & $5.93 \pm 4.85^{\mathrm{ABC}}$ \\
\hline Bomet & $0.881 \pm 0.13^{\mathrm{C}}$ & $16.82 \pm 7.77^{\mathrm{BC}}$ & $5.94 \pm 0.73^{\mathrm{B}}$ & $1.40 \pm 0.39^{\mathrm{B}}$ & $3.49 \pm 4.67^{\mathrm{BC}}$ \\
\hline Ngerende & $1.016 \pm 0.18^{\mathrm{B}}$ & $10.50 \pm 6.08^{\mathrm{C}}$ & $6.85 \pm 0.33^{\mathrm{A}}$ & $2.27 \pm 0.72^{\mathrm{A}}$ & $7.43 \pm 6.22^{\mathrm{AB}}$ \\
\hline Kirumi & $1.214 \pm 0.19^{\mathrm{A}}$ & $41.53 \pm 48.65^{\mathrm{A}}$ & $6.69 \pm 0.40^{\mathrm{A}}$ & $2.41 \pm 0.90^{\mathrm{A}}$ & $8.18 \pm 7.94^{\mathrm{A}}$ \\
\hline Mean & 0.956 & 21.204 & 6.24 & 1.65 & 4.87 \\
\hline
\end{tabular}

$\mathrm{A}, \mathrm{B}, \mathrm{C}, \mathrm{AB}, \mathrm{BC}, \mathrm{ABC}$ Means with different superscripts in the same column are significantly different at $\mathrm{p}<0.05$. 


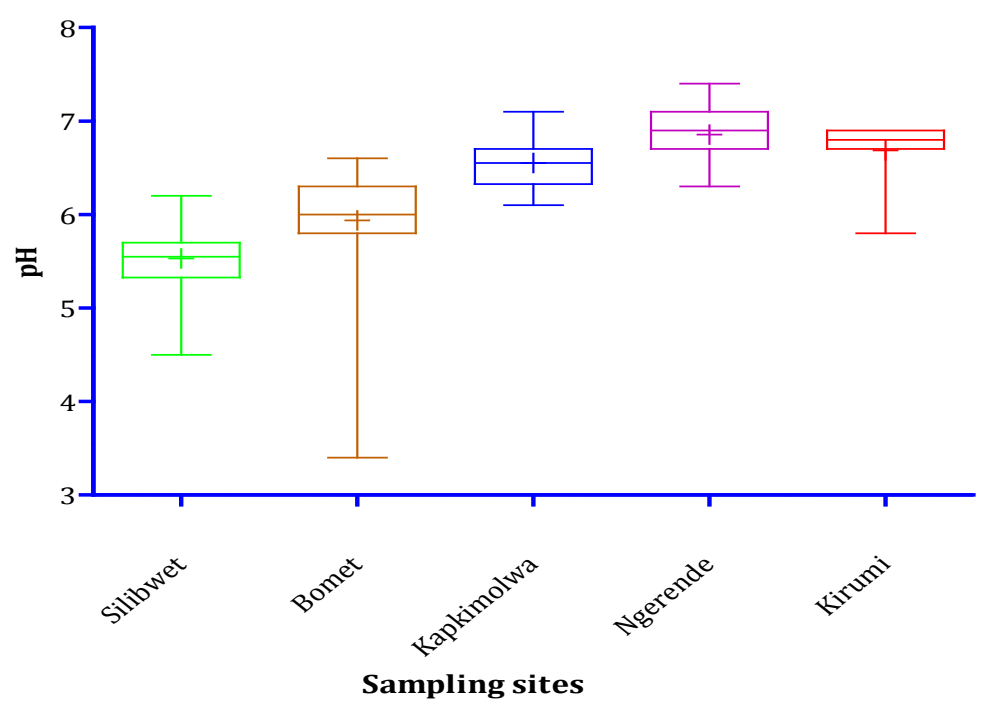

Figure 5. Box plot showing soil $\mathrm{pH}$ from various sampling sites along the Mara River.

showed that percentage soil nitrogen at Kirumi sampling site differed significantly from those recorded at Silibwet and Bomet sampling sites, but did not show any significant difference with those recorded at Kapkimolwa and Ngerende sampling sites.

Further, percentage nitrogen levels recorded at Ngerende, Bomet and Kapkimolwa sampling sites did not however show any significant differences. Silibwet sampling site recorded the lowest mean soil nitrogen, $(2.07 \% \pm$ $2.20 \%$ ) followed by Bomet sampling site-an urban area that recorded $3.49 \% \pm 4.67 \%$ nitrogen (Figure 6).

Percentage soil phosphorus increased downstream with the highest percentage soil phosphorus being recorded at Kirumi followed and lowest at Silibwet samplign site (Figure 7).

\subsection{Soil pH, $\mathrm{N}$ and $\mathrm{P}$ as Influenced by Different Land Use Types and Characteristics}

Soil pH was lowest in soils obtained from pastoral land (fenced) and highest in the agropastoral (combination of crop agriculture and livestock) land which also serves as human settlement area. Percentage nitrogen was highest in agricultural and pastoral land while it was lowest on land use for controlled pastoralism (fenced). Highest phosphorus percentage was recorded in land used for agropastoral land and lowest in agricultural land and human settlement (Table 3).

\subsection{Land Degradation Status Based on Soil Bulk Density}

The mean soil bulk density within the Mara River basin was $0.956 \mathrm{~g} / \mathrm{cm}^{3}$, while there were significant variations in soil bulk density between different land use types (sites) within the Mara River basin (one-way ANOVA, $\mathrm{F}_{4}$, $\left.{ }_{140)}=19.03, \mathrm{p}<0.001\right)$. DMRT further established that mean soil bulk density recorded at Kirumi sampling site was significantly higher than all the other sites, with the highest soil bulk density $\left(1.214 \pm 0.19 \mathrm{~g} / \mathrm{cm}^{3}\right)$ recorded at a grazing field at Kirumi sampling site and lowest $\left(0.867 \pm 0.12 \mathrm{~g} / \mathrm{cm}^{3}\right)$ at atea farm within Silibwet sampling site. However, soil bulk density at Bomet, Kapkimolwa and Silibwet sampling sites did not vary significantly from each other, as was also the case for soil bulk density between Ngerende and Kapkimolwa sampling sites (Table 2 and Figure 8).

\section{Discussion}

Characterization of land use along the Mara River profile provided a clear insight on the various land use types and rating. Mara River Basin exhibited five diverse land uses with forests (trees and shrubs) and mixed agriculture characterizing the upper Mara (Silibwet and Kapkimolwa sampling sites), agriculture, pastureland, and nat- 


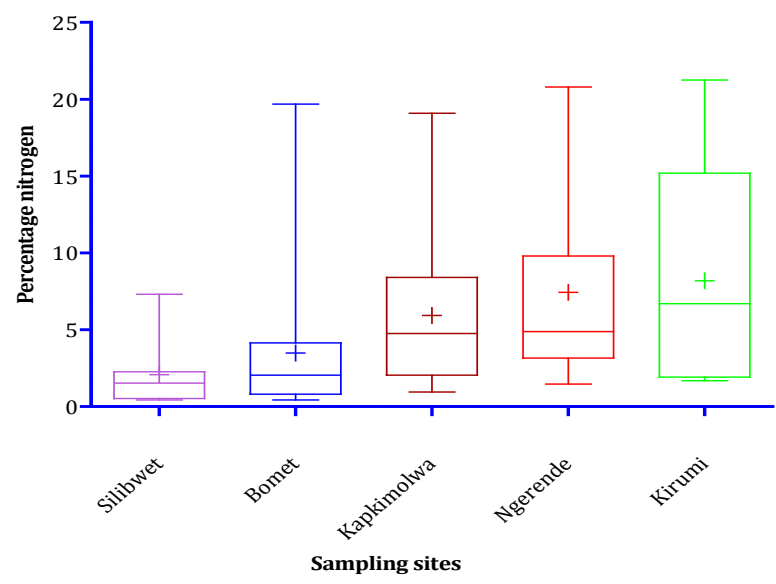

Figure 6. Box plot showing percentage soil nitrogen at various sites within blocks/clusters.

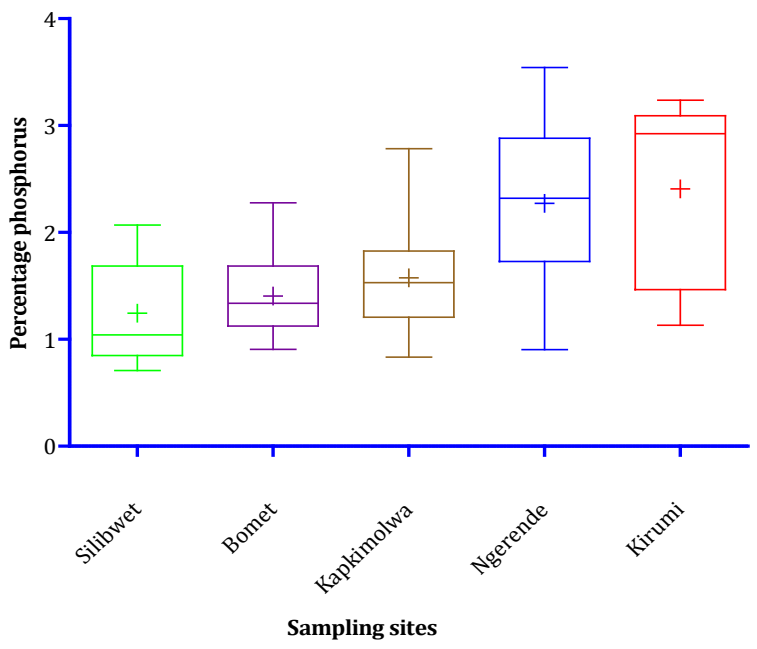

Figure 7. Box plot showing percentage soil phosphorus at different sites along the Mara River profile.

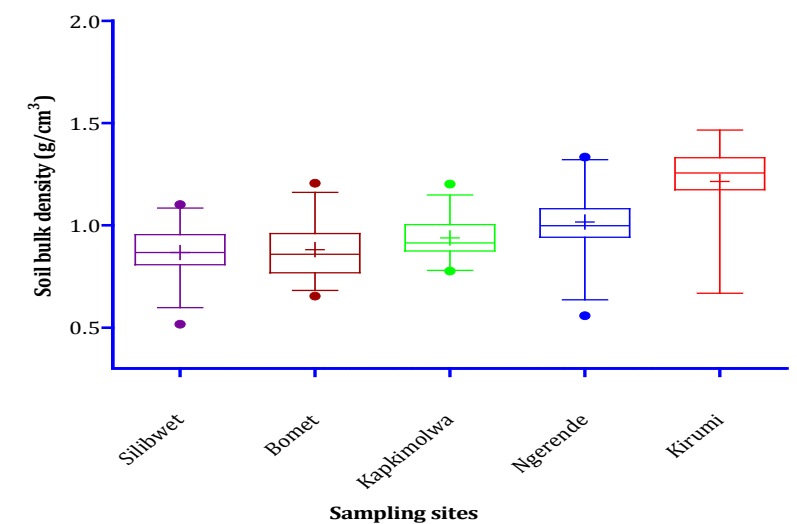

Figure 8. Box plot showing mean soil bulk density at different sites along the Mara River. 
Table 3. Statistics of $\mathrm{pH}, \%$ Nitrogen, and \% Phosphorus by land use types.

\begin{tabular}{cccccccc}
\hline & \multicolumn{2}{c}{$\mathrm{pH}$} & \multicolumn{3}{c}{$\%$} & \multicolumn{2}{c}{$\%$} \\
\cline { 5 - 8 } Land Use Type & \multicolumn{2}{c}{ Nitrogen } & \multicolumn{2}{c}{ Phosphorus } \\
\cline { 5 - 8 } & Mean & s.e & Mean & s.e & Mean & s.e \\
\hline Agricultural \& pastoral land & 5.94 & 0.18 & 0.099 & 1.17 & 0.013 & 0.10 \\
Agricultural land & 6.36 & 0.13 & 0.011 & 0.69 & 0.023 & 0.13 \\
Agricultural land and settlement & 6.43 & 0.13 & 0.018 & 0.64 & 0.010 & 0.66 \\
Agropastoral land & 5.33 & 0.09 & 0.005 & 0.09 & 0.024 & 0.27 \\
Agropastoral \& settlement land & 7 & 0.17 & 0.016 & 0.99 & 0.013 & 0.03 \\
Agropastoral land & 6.12 & 0.13 & 0.015 & 0.86 & 0.014 & 0.14 \\
Ujamaa village since 1967 & 5.8 & 0.12 & 0.008 & 1.47 & 0.023 & 0.55 \\
Pastoral/settlement (school) land & 6.4 & 0.19 & 0.004 & 0.74 & 0.011 & 0.11 \\
Pastoral land (fenced) & 5.42 & 0.31 & 0.014 & 0.03 & 0.012 & 0.08 \\
Pastoral land (range land) & 5.89 & 0.19 & 0.014 & 1.25 & 0.015 & 0.1 \\
\hline
\end{tabular}

ural savanna characterizing the middle (Bomet and Ngerende sampling sites) and parts of the lower basin, and expansive wetlands characterizing the Lower Mara (Kirumi sampling site). Land-use change is primarily influenced by local needs, urbanization and remote economic forces. Land use change at the upper Mara River could have been triggered by the high human population growth, forcing encroachment of forest land for agricultural purposes, livestock grazing and human settlement (including urban development). Consistent with the current study findings, previous studies show that change in land use is highly dependent on the immediate needs of the inhabitants. Different land use types influence land degradation differently, with those used for agriculture and human settlements thought to cause more degradation than those used as pasture land [40]. According to Celik [41] the magnitude of land use changes vary with land use type and land management options applied. However, studies show that while hasty conversion of land use from one type to another may provide a quick remedy to the inhabitants, the long term effect on the land and by extension the aquatic ecosystem nearby may be profound.

Many researchers, including Mugisha [26], Misana et al. [27] and Olson et al. [28], all concur that most of the changes observed in land use in many parts of Africa, are mainly associated with extension and intensification of agricultural activities to new areas. The current findings showed that most plots within Silibwet, Kapkimolwa, Bomet and Ngerende sampling sites that had undergone changes in land use were initially forested before they were converted to farmlands, pasture lands and human settlements. One of the plots in Ngerende which was initially a forested area had also been cleared to create room for construction of a school.

Like in the current study, Maitima et al. [29] while studying the linkages between land use change and land degradation and biodiversity in East Africa, reported that land use changes in East Africa have transformed land cover to farmlands, grazing lands, human settlements and urban centers at the expense of natural vegetation. These changes are associated with deforestation, biodiversity loss and land degradation. Studies by Lambin et al. [42] showed that land conversion to agriculture in East Africa has outpaced the proportional human population growth in recent decades. Natural vegetation cover has given way not only to cropland but also to native or planted pasture [42]. A synthesis of results of long term research by an interdisciplinary team reveals the linkages between land use change, biodiversity loss and land degradation [29]. Maitima et al. [29] reported that land use changes in East Africa have transformed land cover to farmlands, grazing lands, human settlements and urban centers at the expense of natural vegetation. They further observed that land use changes are now associated with deforestation, biodiversity loss and land degradation.

Studies by EAC [43] showed that on average $90 \%$ of the LVB population depends on crop and livestock agriculture as the main land use activity, with farm size often less than 1 hectare. This overdependence on limited land use activities contributes substantially to land degradation. Livestock and wildlife grazing has been cited as a source of soil degradation [44]. However, grazing has also been linked to increased bulk density 
through compaction and exposure of the soil to the sun, but reduces most soil nutrients through feeding and subsequent erosion due to the reduced ground cover [29]. One potentially degrading effect on soil condition is that of soil compaction [45]. Because soil is a complex system of biotic and abiotic components, soil compaction influences several properties of soils that may in turn affect vegetation. These include changes in root growth, availability and movement of air and water, and microbial activity [46]. Established evidence links land use change to losses of soil nutrients among them soil organic carbon, soil nitrogen and soil phosphorus, all of which reduce the productivity of the land, while adjacent aquatic systems are diminished by increased nutrient and sediment load [19].

Studies show that in lands used for pastoral activities, soil compaction can be affected by stocking rates [47] [48], soil texture [47] [49], season of grazing [48], and water content and organic matter [50]. Overgrazing of rangeland; over-cultivation of cropland; water logging; deforestation; and pollution and industrial causes are the most frequently recognized land uses that cause of land degradation [51]. Among the key indicators of land degradation that this study comprehensively used was soil quality, characteristics and productivity. It is acknowledged that land degradation processes are not always induced by man but rather can take natural forms. In the natural state, the rate of water erosion under natural forest corresponds with the subsoil formation rate, hence there is always equilibrium. This boils to the point that accelerated land degradation commonly transpire after human intervention in the environment through different land uses.

Cultivated lands tend to have higher soil bulk densities than forested lands. However, in the current study, soil bulk density and other soil characteristics $(\mathrm{N}, \mathrm{P}$ and $\mathrm{pH})$ at Silibwet sampling block were the lowest compared to all other land use types within the Mara River basin. On the contrary, though they had relatively less human influence, Ngerende and Kirumi sampling blocks recorded significantly higher soil bulk density, $\%$ carbon, \% phosphorus, $\%$ nitrogen as well as soil $\mathrm{pH}$, compared to all other land use types (sites) probably due to wildlife and livestock trampling effects on the top soils which results in pore volumes reduction and thus high soil bulk density as well as accumulation of fertile soils from uplands to the lower reaches of the Mara River basin resulting in the high nutrient levels recorded at this section of the basin. Consistent with the current study findings, Christensen et al. [52] also demonstrated that total nitrogen and total phosphorus concentrations were highest at sampling sites with little to no agricultural activities such as Ngerende and Kirumi and lower at sampling sites that had a higher percentage of agricultural activities such as Kapkimolwa.

Soil Infiltration rates can be linked to two factors mainly the soil texture and bulk density [53]. The low infiltration rates recorded in some sampling sites such as Silibwet and Kapkimolwa could possibly be due to soil compaction from the perennial farming activities as well as due to cattle trampling effect among other factors. Studies show that soil texture controls the infiltration rate and the amount of water that can be stored in a given thickness of soil for plant use [53]. Clay soils for instance provide the highest surface area, but if clay content is great enough to restrict air and water movement, these critical variables may limit its productivity. Soils in the pure sand range on the other hand have high rates of water infiltration but are low in productivity because they do not retain water or nutrients [53]. The ideal substrate is therefore texturally balanced soil in the loam range [54].

Land use has significant effects on soil chemical properties. Different studies have examined the effects of land use on soil physico-chemical properties [6]-[8]. The levels of soil nutrients ( $\mathrm{P}$ and $\mathrm{N})$, soil bulk density and soil infiltration rates can be used to deduce the degree at which a given site is degraded. Majule [55] and Gachimbi [56] reported that soils in areas with continuous cultivation and without appropriate management practices have low fertility levels due to overutilization. Various researchers have however reported that agricultural intensification often includes a substantial increase soil nitrogen emanating from the increased application of nitrogen $(\mathrm{N})$ fertilizer, which improves yields but has deleterious consequences on adjacent aquatic systems, where nutrient loading can lead to eutrophication [57] [58]. It is however possible that nutrient uptake by crops, leaching during heavy downpours or further removal during plant harvest time could have contributed to the relatively low soil nutrient levels at Silibwet (an agricultural area) compared to other terrestrial sampling blocks downstream, while the upper ridges and urban areas like Bomet town are also susceptible to erosive nature of landscapes especially during heavy down pours which could have facilitated the active removal of top-soil nutrients especially soil nitrogen and increased erosion through runoff leaving the uplands devoid of the fertile topsoil, which are instead swept into the stream.

In this study, soil phosphorus, soil nitrogen and soil $\mathrm{pH}$ were assessed, to determine variations among different land use types. Studies by Maitima et al. [29] reported that grazed sites were significantly higher in soil pH 
and lower in bulk density, nitrogen, moisture content, percent organic matter and organic carbon than un-grazed sites $(\mathrm{p}<0.05)$. This is a further indication that livestock and wildlife grazing activities have significant effects on soil properties with subsequent effect on water quality. The current study findings showed that soil characteristics as measured by various soil parameters including soil nutrients and soil $\mathrm{pH}$ varied significantly under different land use types along the Mara River.

The mean soil $\mathrm{pH}$ recorded in this study was 6.24 , implying that the soils within the Mara River basin were slightly acidic. The soil $\mathrm{pH}$ of soil samples from Silibwet sampling site-which is a relatively forested site and Bomet sampling site-which was characterized by urban land use, were relatively low probably as a result of washing out of solutes from these parts as was also reported in the central highlands of Eastern Ethiopia by Mohammed et al. [59]. The high acidity at highly agricultural lands could be attributed to the decomposition and formation of carboxylic acid during the farming process. Weak acids (corresponding to vinegar) are produced in the soil when plant residues and organic matter decompose. These weak acids react and readily combine with nutrients such as calcium, magnesium, potassium, and sodium as the soil solution (water) moves down through and below the root zone (leaching). During this process, if soil $\mathrm{pH}$ is less than 5.2, hydrogen or aluminium replaces basic cations causing the soil in the leached zone to become more acidic [60]. Tamirat [61] also attributed soil $\mathrm{pH}$ of an area to the nature of the parent material, climate of the region, organic matter and topographic situation.

The relatively acidic nature of the soils could also be attributed to the high rainfall resulting in the leaching of some basic cations especially calcium from the surface horizons of the soils [62]. A pH value of less than 5.5 like that recorded at Silibwet sampling site is considered problematic for most microbial activities, and this directly influences availability of nutrients to plant [63]. Consistent with the findings of Ahmed [64], continuous cultivation practices, excessive precipitation, steepness of the topography and application of inorganic fertilizer could also have resulted to the reduction of $\mathrm{pH}$ in the soil profile particularly at Silibwet sampling site where agricultural activities especially tea plantations were most dominant. Juo and Manu [65] also reported that growing vegetation tended to decrease soil $\mathrm{pH}$, a phenomenon they related to cation uptake by plant, with subsequent release of $\mathrm{H}+$ ions, organic matter decomposition into organic acids, increased carbon dioxide levels through root respiration and nitrification. Bobbink et al. [66], however, reported that low soil $\mathrm{pH}$ can decrease plant diversity in forests especially when the soil $\mathrm{pH}$ is less than 4.2 making aluminium potentially toxic.

The relatively high soil $\mathrm{pH}$ at Ngerende sampling site could be attributed to low organic matter input in the grazing fields and probably accumulation of bases resulting from a compromised hydraulic conductivity that results from minimum leaching of the soluble bases. Simmons [67] reported that as soil $\mathrm{pH}$ increases above 6.5, potassium mobility slows down, and as the soil $\mathrm{pH}$ reaches 7.0, mobility is severely hindered making it unavailable. This is important as three of the five sites sampled within the Mara River basin recorded $\mathrm{pH}$ levels greater than 6.5. It was however interesting to note that high $\mathrm{pH}$ on land did not necessarily correlate directly to high $\mathrm{pH}$ levels in water. This was clear at Ngerende sampling site whereby land $\mathrm{pH}$ was amongst the highest but the same site recorded the lowest water $\mathrm{pH}$, probably implying that $\mathrm{pH}$ in water was not necessarily driven or impacted by adjacent terrestrial soil $\mathrm{pH}$. A number of studies show that in cropped fields, the ash deposited by the common practice of slash-and-burn releases alkaline cations ( $\mathrm{Ca}, \mathrm{Mg}$ and $\mathrm{K}$ ), causing high $\mathrm{pH}$, and low exchangeable Aluminium values [65]. This could probably explain the relatively high $\mathrm{pH}$ values recorded at Kapkimolwa, Ngerende and Kirumi sampling sites, as most studies have reported that most agricultural land is regularly limed to undo the effects of natural acidification. Studies show that many acid soils "fix" or hold phosphorus, making it unavailable for plant growth. Soil acidity can also be a barrier to root development, limiting the plants' ability to reach moisture in the sub-soil. In the humid tropics, soil acidity and associated problems often lead to land abandonment and the perpetuation of slash-and-burn agriculture [68].

Although mean soil $\mathrm{pH}$ across most of the land use types in the current study were higher than the critical value of 5.5, mean soil $\mathrm{pH}$ at Silibwet block was much lower than the critical value. Consistent with our findings, studies show that soils from tea plantations as was the case at Silibwet tend to be strongly acidic, with some as less as 4.5 [69]. The low $\mathrm{pH}$, at Silibwet sampling site corresponded with a high soil organic carbon at the same site. The long-term effect of fertilizer application could have been attributed to the low $\mathrm{pH}$ and high soilorganic carbon as was also observed by Wang et al. [70] in commercial tea plantations in China.

Nitrogen and phosphorus are essential nutrients for growth and development of crops, whose optimal levels in the soil is indicative of the productivity of the soil [71]. However, soils in areas with continuous cultivation and without appropriate management practices often have low soil fertility levels due to over utilization with studies 
further showing that major plant nutrients, e.g., potassium (K) and phosphorous (P) are the soil properties most affected by cultivation over time [55] [56]. The mean percentage soil nitrogen across all sampling blocks was $4.87 \%$, with significant differences observed in percentage soil nitrogen $\left(\mathrm{F}_{(4,63)}=3.26, \mathrm{p}<0.006\right)$ between sampling sites. The continuous conversion of vegetated areas to non-vegetated surfaces as was the case at Bomet sampling site could have resulted in the reduced soil nutrients through increased soil erosion, while the significantly low nitrogen and phosphorus proportions in soils from Silibwet sampling site could have been due to crop (mainly tea) uptake as well as additional loss through food crop harvests or when vegetation is uprooted during land preparation as was also observed by Elliot [72].

Studies show that though its consequences vary, land conversion frequently leads to nutrient losses through disruption of surface and mineral horizons (e.g. by mechanical disturbance) and reduction of organic matter inputs. Cultivation of forests, for example, diminishes soil carbon within a few years of initial conversion and substantially lowers mineralizable nitrogen [11]. Phosphorus is critical to biotic function and essential to the development and maintenance of ecosystems [73]-[75]. It is an essential element classified as a macronutrient because of the relatively important part it plays in the growth of plants. However its mismanagement can pose a threat to water quality of adjacent aquatic systems. In the current study, percentage phosphorus levels varied significantly between different sites/land use types $(\mathrm{p}<0.0001)$ with DMRT further establishing that Ngerende and Kirumi sampling sites located at the lower Mara River Basin had significantly higher percentage phosphorus compared to the other three sites (Silibwet, Kapkimolwa and Ngerende sampling sites). Just like nitrogen, the relative low phosphorus percentages recorded at the sites located on the upper catchment particularly Silibwet, Bomet and Kapkimolwa where crop farming was dominant could have been due to removal by the crops' edible parts and plant residues. Mohammed et al. [59] linked the variability of phosphorus levels to land use, altitude, slope position and other characteristics, such as clay and calcium carbonate content. Further analysis established significant differences in percentage phosphorus level between different vegetation types.

Studies have also shown that soils devoted to crop production can lose far more phosphorus than soils that are covered by relatively undisturbed forest or natural grass land [76]. Phosphorus is an essential nutrient for plant growth hence its' active uptake by plants and subsequent removal through harvest can have an acidifying effect on the soils. Studies show that the amount of nutrients removed by cropping depends on the type of crop grown, part of the crop harvested, and the stage of growth at harvest [77]. Silibwet sampling site which is a relatively forested area characterized by small scale farms recorded the lowest phosphorus percentage compared to all the other sites, probably as a result of continuous cultivation that facilitated phosphorus uptake and removal by food crops during harvest. Livestock and wildlife herbivory can also cause shifts in plant species composition by replacing highly palatable grasses with unpalatable species [78] and therefore cause changes in soil nutrients indirectly. This is because as vegetation cover declines, soil nutrients are also depleted, while soil erosion increases, generating negative consequences on rangeland productivity [79]. Due to severe grazing, a reduction in plant biomass leads to depletion of existing nutrients among them nitrogen and phosphorus thus resulting in soil fertility reduction [79].

Soil bulk density is highly dependent on soil texture and the densities of soil mineral (sand, silt, and clay) and organic matter particles, as well as their packing arrangement [80]. Further, bulk density is influenced by crop and land management practices that affect soil cover, organic matter, soil structure, and/or porosity. In the current study, the mean soil bulk density within the Mara River basin was $0.956 \mathrm{~g} / \mathrm{cm}^{3}$, while there were significant variations in soil bulk density between different land use types (sites) within the Mara River basin $\left(\mathrm{F}_{(4,140)}=\right.$ $19.03, \mathrm{p}<0.001)$. Most soil bulk densities fall between $1.0 \mathrm{~g} / \mathrm{cm}^{3}$ and $2.0 \mathrm{~g} / \mathrm{cm}^{3}$; while root penetration is severely impacted at bulk densities greater than $1.6 \mathrm{~g} / \mathrm{cm}^{3}$ [81]. As density increases, pore space decreases and the amount of air and water held in the soil also decreases [81]. In the current study, high soil bulk density observed at the lower Mara River watershed compared to other sites upstream could have been contributed by the high livestock and wild life population at those areas which together with farming activities might have had an impact on the soil structure thus increasing the bulk density and subsequently contributed to land degradation. Studies show that lower soil bulk density is desirable for plant growth, whether those plants are agricultural crops, trees, or turf grass [82]. This is because low bulk density soils have greater water infiltration rates which minimize runoff, improve water quality, and reduce storm water flow [80].

Activities such as plowing, timber harvesting or compaction of the soil during home construction, some of which were observed at the Mara River basin can however increase soil bulk density and reduce pore space. Compacted soils may result in little to no vegetation growth in some locales [83]. The high land degradation 
status at the lower Mara River was also manifested in the high turbidity and nutrient concentration (i.e. total nitrogen and total phosphorus) recorded in the adjacent waters of the Mara River at this point. There was also surface runoff and soil erosion increase because these soils had lost the ability to absorb rain water. Some guidelines to minimize the damage caused by compaction include confining traffic to designated paths; reducing livestock population per unit area among others can control erosion [84].

The significant differences in soil bulk density that existed between Nyangores and Amala and those observed at the lower Mara sub-catchments represents spatial processes occurring along the length of the river, with reduced human impact and high vegetation cover at the upland areas probably protecting soils from degradation thus leading to low bulk density. Likewise, several researchers have also reported that increased land degradation can be accelerated by the position of the land within a landscape, with lowland areas likely to suffer impacts of increased erosion, surface runoff and silt deposition, thus resulting in high bulk density [85] [86]. Silibwet sampling site which was relatively forested and with a relatively large area covered by tea plantation recorded significantly low soil bulk density, high soil conductivity and live biomass compared to all other land use types. However, bulk density recorded within Bomet and Kapkimolwa sampling sites, both located at the upper Mara River basin, were relatively higher compared to those at Silibwet.

In the current study, areas where land use types alternated between cultivated and grazing fields recorded intermediate mean soil bulk density between the agricultural crop lands and grazing fields. This is explained by the intermediate amount of litter inputs, vegetation cover and the moderate level of surface ground disturbance due to seasonality alteration of use. The ability of livestock to alter soil bulk densities is a function of stocking density and intensity of the same land use [43]. Studies show that livestock activities like simple grazing often results in soil compaction due to the weight of the animals and the mechanical forces that cattle apply when walking on land [87]. Soil compaction may in turn have negative consequences such as reduced rainfall infiltration, enhanced soil erosion [88] and degradation of the herbaceous vegetation cover [89] [90].

\section{Conclusion}

Based on the current study findings, it was presumed that land use changes in the low land areas of the Mara River Basin took place earlier than in the uplands, as exhibited by the differences in soil particle sizes in soil bulk densities recorded at different points along the river. This phenomenon can also explain relatively low soil bulk density at Silibwet, Bomet, and Kapkimolwa sampling sites as opposed to high soil bulk density and low soil conductivity recorded in Ngerende and Kirumi sampling sites. These results point to the need to have focused policies on integrated land and water resource management strategies in the Mara River Basin.

\section{Acknowledgements}

East Africa Community-Lake Victoria Basin Commission Secretariat (EAC-LVBC) provided funds for this study. We are grateful to the Kenya Forestry Research Institute (KEFRI), Maseno, Kenya for providing the time, material, and technical support.

\section{References}

[1] Burcher, C.L., Vallet, H.M. and Benfield, E.F. (2007) The Land Cover Cascade. Relationship Coupling Land and Water. Ecology, 88, 228-242. http://dx.doi.org/10.1890/0012-9658(2007)88[228:TLCRCL]2.0.CO;2

[2] Eswaran, H., Lal, R. and Reich, P.F. (2001) Land Degradation: An Overview. In: Bridges, E.M., Hannam, I.D., Oldeman, L.R., Pening de Vries, F.W.T., Scherr, S.J. and Sompatpanit, S., Eds., Responses to Land Degradation, Proceedings of 2nd International Conference on Land Degradation and Desertification, Khon Kaen, Thailand. Oxford Press, New Dehli, India. Kaen, Thailand. Oxford Press, New Dehli, India.

[3] Bai, Z.G., Dent, D.L., Olsson, L. and Schaepman, M.E. (2008) Proxy Global Assessment of Land Degradation. Soil Use Management, 24, 223-234. http://dx.doi.org/10.1111/j.1475-2743.2008.00169.x

[4] Jones, K.B., Slonecker, E.T., Nash, M.S., Neale, A.C., Wade, T.G. and Hamann, S. (2010) Riparian Habitat Changes across the Continental United States (1972-2003) and Potential Implications for Sustaining Ecosystem Services. Landscape Ecology, 25, 1261-1275.http://dx.doi.org/10.1007/s10980-010-9510-1

[5] Food and Agriculture Organization (FAO) (2005) Global Forest Resources Assessment 2005. Progress towards Sustainable Forest Management. Forestry Paper 147, Rome.

[6] Emadi, M., Baghernejad, M., Fathi, H. and Saffari, M. (2008) Effect of Land Use Change on Selected Soil Physical 
and Chemical Properties in North Highlands of Iran. Journal of Applied Sciences, 8, 496-502. http://dx.doi.org/10.3923/jas.2008.496.502

[7] Agoume, V. and Birang, A.M. (2009) Impact of Land-Use Systems on Some Physical and Chemical Soil Properties of an Oxisol in the Humid Forest Zone of Southern Cameroon. Tropicultura, 27, 15-20.

[8] Gol (2009) Effects of Land Use Change on Soil Properties and Organic Carbon at Dagdami River Catchment in Turkey. Journal of Environmental Biology, 30, 825-830.

[9] Lake Victoria Basin Commission (LVBC) (2007) Regional Transboundary Diagnostic Analysis (RTDA) of Lake Victoria Basin. No. 4, Lake Victoria Basin Commission Publication, Kisumu.

[10] Rai, S.C. and Sharma. E. (1998) Comparative Assessment of Runoff Characteristics under Different Land Use Patterns within a Himalayan Watershed. Hydrological Process, 12, 2235-2248. http://dx.doi.org/10.1002/(SICI)1099-1085(19981030)12:13/14<2235::AID-HYP732>3.0.CO;2-5

[11] Murty, D., Kirschbaum, M.F.U., Mcmurtrie, R.E. and Mcgilvray, H. (2002) Does Conversion of Forest to Agricultural Land Change Soil Carbon and Nitrogen? A Review of the Literature. Global Change Biology, 8, 105-123. http://dx.doi.org/10.1046/j.1354-1013.2001.00459.x

[12] Richter, D.D., Markewitz, D., Heine, P.R., Jin, V., Raikes, J., Tian, K. and Wells, C.G. (2000) Legacies of Agriculture and Forest Regrowth in the Nitrogen of Old-Field Soils. Forest Ecology and Management, 138, 233-248. http://dx.doi.org/10.1016/S0378-1127(00)00399-6

[13] Islam, K.R. and Weil, R.R. (2000) Land Use Effects on Soil Quality in a Tropical Forest Ecosystem of Bangladesh. Agriculture, Ecosystems and Environment, 79, 9-16. http://dx.doi.org/10.1016/S0167-8809(99)00145-0

[14] Benoit, M. and Fizaine, G. (1999) Quality of Water in Forest Catchment Areas. Revue Forestiere Francaise, 50, 162172.

[15] Berka, C., Schreier, H. and Hall, K. (2001) Linking Water Quality with Agricultural Intensification in a Rural Watershed. Water, Air, and Soil Pollution, 127, 389-401. http://dx.doi.org/10.1023/A:1005233005364

[16] Wang, X. (2001) Integrating Water Quality Management and Land Use Planning in a Watershed Context. Journal of Environmental Management, 61, 25-36. http://dx.doi.org/10.1006/jema.2000.0395

[17] Liu, C.M. and Liu, X.Y. (2009) Healthy River and Its Indication, Criteria and Standards. Journal of Geographical Sciences, 19, 3-11. http://dx.doi.org/10.1007/s11442-009-0003-6

[18] Alin, S.R., Eilly, O.R., Ohen, C.M.C., Ettman, A.S.D., Alacios, D.L.P., Fest, M.R. and Mckee, B.A. (2002) Effects of Land-Use Change on Aquatic Biodiversity: A View from the Paleorecord at Lake Tanganyika, East Africa. Geology, 30, 1143-1146. http://dx.doi.org/10.1130/0091-7613(2002)030<1143:EOLUCO $>2.0 . C O ; 2$

[19] Tong, S.T.Y. and Chen, W. (2002) Modeling the Relationship between Land Use and Surface Water Quality. Journal of Environmental Management, 66, 377-393.

[20] Ngoye, E. and Machiwa, J.F. (2004) The Influence of Land-Use Patterns in the Ruvu River Watershed on Water Quantity in the River System. Physics and Chemistry of the Earth, 29, 1161-1166. http://dx.doi.org/10.1016/i.pce.2004.09.002

[21] King, R.S., Baker, M.E., Whigham, D.F., Weller, D.E., Jordan, T.E., Kazyak, P.K. and Hurd, M.K. (2005) Spatial Considerations for Linking Watershed Land Cover to Ecological Indicators in Streams. Ecological Applications, 15, 137-153. http://dx.doi.org/10.1890/04-0481

[22] Sponseller, R.A., Benfield, E.F. and Valett, H.M. (2001) Relationships between Land Use, Spatial Scale, and Stream Macroinvertebrate Communities. Freshwater Biology, 46, 1409-1424. http://dx.doi.org/10.1046/j.1365-2427.2001.00758.x

[23] Houlahan, J.E. and Findlay, C.S. (2004) Estimating the "Critical" Distance at Which Adjacent Land-Use Degrades Wetland Water and Sediment Quality. Landscape Ecology, 19, 677-690. http://dx.doi.org/10.1023/B:LAND.0000042912.87067.35

[24] Seitzinger, S.P., Mayorga, E., Bouwman, A.F., Kroeze, C., Beusen, A.H.W., Billen, G., Van Drecht, G., Dumont, E., Fekete, B.M., Garnier, J., Harrison, J., Wisser, D. and Wollheim, W.M. (2010) Global River Nutrient Export: A Scenario Analysis of Past and Future Trends. Global Biogeochemical Cycles, 24, 1-16. http://dx.doi.org/10.1029/2009GB003587

[25] Dwasi, J.A. (2002) Trans-Boundary Environmental Issues in East Africa: An Assessment of the Environmental and Socio-Economic Impacts of Kenya's Forestry Policy. Nairobi.

[26] Mugisha, S. (2002) Root Causes of Land Cover/Use Change in Uganda: An Account of the Past 100 Years. LUCID Working Paper No.14, International Livestock Research Institute, Nairobi. WWW.Lucideastafrica.org

[27] Misana, S.B., Majule, A.E. and Lyaruu, H.V. (2003) Linkages between Changes in Land Use, Biodiversity and Land Degradation on the Slopes of Mount Kilimanjaro, Tanzania. LUCID Working Paper No. 38, International Livestock 
Research Institute, Nairobi.

[28] Olson, J.M., Misana, S.B., Campbell, D.J., Mbonile, M.J. and Mugisha, S. (2004) The Spatial Pattern and Root Causes of Land Use Change in East Africa. LUCID Working Paper No. 4, International Livestock Research Institute, Nairobi. WWW.Lucideastafrica.org

[29] Maitima, J.M., Mugatha, S.M., Reid, R.S., Gachimbi, L.N., Majule, A., Lyaruu, H., Pomery, D., Mathai, S. and Mugisha, S. (2009) The Linkages between Land Use Change, Land Degradation and Biodiversity across East Africa. African Journal of Environmental Science and Technology, 3, 310-325.

[30] ICRAF (2002) Improved Land Management in the Lake Victoria Catchment. Linking Land and Lake, Research and Extension, Catchment and Lake.

[31] Mati, B.M., Mutie, S., Home, P., Mtalo, F. and Gadain, H. (2005) Land Use Changes in the Trans-Boundary Mara Basin: A Threat to Pristine Wildlife Sanctuaries in East Africa. Proceedings of the 8th International River Symposium, Brisbane, 6-9 September 2005.

[32] WWF (2009) Mara River Basin Trans-Boundary Water Resources Management Programme Progress Report. Nairobi.

[33] Government of Kenya (2009) The Mau Taskforce Report. Prime Minister's Office, Republic of Kenya, Nairobi.

[34] USAID EA (2010) Assessing Environmental Flows for the Mara River. Nairobi.

[35] Mutie, S.M., Mati, B., Home, P., Gadain, H. and Gathenya, J. (2006) Evaluating Land Use Change Effects on River Flow Using USGS Geospatial Stream Flow Model in Mara River Basin, Kenya. Center for Remote Sensing of Land Surfaces, Bonn, 28-30 September 2006.

[36] Nile Equatorial Lakes Subsidiary African Program (NELSAP) (2002) Management of the Water Resources of the Mara River Basin. Project Identification No.3, 1-13.

[37] Ben-Dor, E., Irons, J.R. and Epema, G.F. (1999) Soil Reflectance. In: Rencz, N., Ed., Remote Sensing for the Earth Sciences: Manual of Remote Sensing, John Wiley \& Sons, New York, 111-188.

[38] Hunt, G.R. and Salisbury, J.W. (1970) Visible and Near-Infrared Spectra of Minerals and Rocks. I. Silicate Minerals. Modern Geology, 1, 283-300.

[39] Reynolds, W.D. and Elrick, D.E. (1990) Ponded Infiltration from a Single Ring: I. Analysis of Steady Flow. Soil Science Society of America Journal, 54, 1233-1241. http://dx.doi.org/10.2136/sssaj1990.03615995005400050006x

[40] Greijn, H. (1994) A Missed Opportunity. Our Planet, 6, 23-24.

[41] Celik, I. (2005) Land Use Effects on Organic Matter and Physical Properties of Soil in a Southern Mediterranean Highland of Turkey. Soil \& Tillage, 83, 270-277. http://dx.doi.org/10.1016/j.still.2004.08.001

[42] Lambin, E.F., Geist, H.J. and Lepers, E. (2003) Dynamics of Land Use and Land Cover Change in Tropical Regions. Annual Review of Environment and Resources, 28, 206-241. http://dx.doi.org/10.1146/annurev.energy.28.050302.105459

[43] East African Community (2005) Potentials and Constraints of Promoting Lake Victoria Basin as a Regional Economic Growth Zone. EAC, Arusha.

[44] Dregne, H., Kassas, M. and Rozanov, B. (1991) A New Assessment of the World Status of Desertification. Desertification Control Bulletin, 20, 6-18.

[45] Soane, B.D. and Van Ouwerkerk, C., Eds. (1994) Soil Compaction in Crop Production. Developments in Agricultural Engineering Series, Volume 11. Elsevier Science, Amsterdam, 662.

[46] Lal, R. (2005) Forest Soils and Carbon Sequestration. Forest Ecology and Management, 220, 242-258. http://dx.doi.org/10.1016/j.foreco.2005.08.015

[47] Van Haveren, B.P. (1983) Soil Bulk Density as Influenced by Grazing Intensity and Soil Type on a Short Grass Prairie Site. Journal of Range Management, 36, 586-588. http://dx.doi.org/10.2307/3898346

[48] Naeth, M.A., Pluth, D.J., Chnnasyk, D.S., Bailey, A.W. and Fedkenheuer, A.W. (1990) Soil Compacting Impacts of Grazing in Mixed Prairie and Fescue Grassland Ecosystems of Alberta. Canadian Journal of Soil Science, 70, 157-167. http://dx.doi.org/10.4141/cjss90-018

[49] Orr, H.K. (1960) Soil Porosity and Bulk Density on Grazed and Protected Kentucky Bluegrass Range in the Black Hills. Journal of Range Management, 13, 80-86. http://dx.doi.org/10.2307/3895129

[50] Howard, R.F., Singer, M.J. and Frantz, G.A. (1981) Effects of Soil Properties, Water Content, and Compactive Effort on the Compaction of Selected California Forest and Range Soils. Soil Science Society of America Journal, 45, 231236. http://dx.doi.org/10.2136/sssaj1981.03615995004500020001x

[51] Stocking, M. and Murnaghan, N. (2000) Land Degradation-Guideline for Field Assessment. Overseas Development Group, University of East Anglia, Norwich.

[52] Christensen, V.G., Lee, K.E., Sanocki, C.A., Mohring, E.H. and Kiesling, R.L. (2009) Water Quality and Biological 
Responses to Agricultural Land Retirement in Streams of the Minnesota River Basin, 2006-2008. US Geological Survey Scientific Investigations Report 2009-5215, USGS, Reston, VA.

[53] USDA-NRCS (2001) Rangeland Soil Quality: Water Erosion. Soil Quality Information Sheet. http://soils.usda.gov/sqi

[54] Tiedemann, A.R. and Lopez, C.F. (2004) Assessing Soil Factors in Wildland Improvement Programs. In: Monsen, S.B., Stevens, R. and Shaw, N.L. (Compilers), Restoring Western Ranges and Wildlands, USDA Forest Service, Rocky Mountain Research Station, Fort Collins, General Technical Report RMRS-GTR-136-Vol. 1, 39-56.

[55] Majule, A.E. (2003) A Study on Land Use Types, Soils and Linkages between Soils and Biodiversity along the Slopes of Mt. Kilimanjaro, Tanzania.

[56] Gachimbi, L.N. (2002) Technical Report of Soil Survey and Sampling Results: Embu-Mbeere Districts, Kenya. LUCID Working Paper Series No. 9, KARI-Kabete, Nairobi.

[57] Beman, J.M., Arrigo, K.R. and Matson, P.A. (2005) Agricultural Runoff Fuels Large Phytoplankton Blooms in Vulnerable Areas of the Ocean. Nature, 434, 211-214. http://dx.doi.org/10.1038/nature03370

[58] Turner, R.E. and Rabalais, N.N. (1991) Changes in Mississippi River Water Quality This Century. BioScience, 41, 140-147. http://dx.doi.org/10.2307/1311453

[59] Mohammed, A., Leroux, P.A.L., Barker, C.H. and Heluf, G. (2005) Soil of Jelo Micro-Catchment in the Central Highlands of Eastern Ethiopia. I. Morphological and Physiochemical Properties. Ethiopian Journal of Natural Resource, 7 , 55-81.

[60] Spies, C.D. and Harms, C.L. (2004) Soil Acidity and Liming of Indiana Soils. Purdue University, West Lafayette. www.agry.purdue.edu/ext/forages/publications/ay267.htm

[61] Tamirat, T. (1992) Vertisol of Central Highlands of Ethiopia: Characterization and Evaluation of Phosphorus Statues. Master's Thesis, Alemaya University, Dire Dawa.

[62] Iwara, A.I. (2011) Soil Erosion and Nutrient Loss Dynamics in Successional Fallow Communities in a Part of the Rainforest Belt, South-Southern Nigeria. Ph.D. Proposal Presented at the Staff/Postgraduate Seminar, University of Ibadan, Ibadan.

[63] Solomon, D. (2008) Presentation on the Relationships Existing in Minerals Soil between pH on the One Hand and the Activity of Microorganisms and the Availability of Plant Nutrients on the Other. Bahir Dar University, Bahir Dar.

[64] Ahmed, H. (2002) Assessment of Spacial Variability of Some Physicochemical Property of Soil under Different Elevation and Land Use Systems in the Western Slopes of Mount Chilalo, Arisi. Master's Thesis, Alemaya University, Dire Dawa.

[65] Juo, A.S.R. and Manu, A. (1996) Chemical Dynamics in Slash-and-Burn Agriculture. Agriculture, Ecosystems Environment, 58, 49-60.

[66] Bobbink, R., Hornung, M. and Roelofs, J.G.M. (1998) The Effects of Air-Borne Nitrogen Pollutants on Species Diversity in Natural and Semi-Natural European Vegetation. Journal of Ecology, 86, 717-738. http://dx.doi.org/10.1046/j.1365-2745.1998.8650717.x

[67] Simmons, J. (1998) Balancing Soil Nutrition. Rutgers Turf Management Program.

[68] TropSoils (1991) Technical Report for 1988-1989. TropSoils Management Entity, Raleigh, 357 p.

[69] Brady, N. (1990) The Nature and Properties of Soils. 13th Edition, Macmillan, New York.

[70] Wang, R., Shi, X., Wei, Y., Yang, X. and Uoti, J. (2006) Yield and Quality Responses of Citrus (Citrus reticulate) and Tea (Podocarpus fleuryi Hickel.) to Compound Fertilizers. Journal of Zhejiang University Science, 7, 696-701. http://dx.doi.org/10.1631/jzus.2006.B0696

[71] Zhao, Q., Zeng, D.H., Fan, Z.P. and Lee, D.K. (2008) Effect of Land Cover Change on Soil Phosphorus Fractions in Southeastern Horqin Sandy Land, Northern China. Pedosphere, 18, 741-748. http://dx.doi.org/10.1016/S1002-0160(08)60069-7

[72] Elliot, W.J. (2003) Soil Erosion in Forest Ecosystems and Carbon Dynamics. In: Kimble, J.M., Heath, L.S., Birdsey, R.A. and Lal, R., Eds., The Potential of US Forest Soils to Sequester Carbon and Mitigate the Greenhouse Effect, CRC Press, Boca Raton, 175-190.

[73] Richter, D.D., Allen, H.L., Li, J.W., Markewitz, D. and Raikes, J. (2006) Bioavailability of Slowly Cycling Soil Phosphorus: Major Restructuring of Soil P Fractions over Four Decades in an Aggrading Forest. Oecologia, 150, $259-271$. http://dx.doi.org/10.1007/s00442-006-0510-4

[74] Crews, T.E., Kitayama, K., Fownes, J.H., Riley, R.H., Herbert, D.A., Muellerdombois, D. and Vitousek, P.M. (1995) Changes in Soil Phosphorus Fractions and Ecosystem Dynamics across a Long Chronosequence in Hawaii. Ecology, 76, 1407-1424. http://dx.doi.org/10.2307/1938144

[75] Turner, B.L. and Engelbrecht, B.M.J. (2011) Soil Organic Phosphorus in Lowland Tropical Rain Forests. Biogeoche- 
mistry, 103, 297-315. http://dx.doi.org/10.1007/s10533-010-9466-x

[76] Brady, N.C. and Weil, R.R. (1996) The Nature and Properties of Soil. 11th Edition, Prentice-Hall, Inc., Englewood Cliff, $740 \mathrm{p}$.

[77] Whibread, A., Blair, G., Konboon, Y., Lefroy, R. and Naklang, K. (2003) Managing Crop Residues, Fertilizers and Leaf Litters to Improve Soil C, Nutrient Balances, and the Grain Yield of Rice and Wheat Cropping Systems in Thailand and Australia. Agriculture, Ecosystems \& Environment, 100, 251-263. http://dx.doi.org/10.1016/S0167-8809(03)00189-0

[78] Owen-Smith, N. (1999) The Animal Factor in Veld Management: Implications of Selective Patters of Grazing. In: Tainton, N.D., Ed., Veld Management in South Africa, University of Natal Press, Pietermaritzburg, 129-130.

[79] Morgan, R.P.C. (1995) Soil Erosion and Conservation. 2nd Edition, Longman Group, Essex.

[80] Sakin, E., Deliboran, A. and Tutar, E. (2011) Bulk Density of Harran Plain Soils in Relation to Other Soil Properties. African Journal of Agricultural Research, 6, 1750-1757.

[81] Froese, K. (2004) Bulk Density, Soil Strength, and Soil Disturbance Impacts from a Cut-to-Length Harvest Operation in North Central Idaho. Master's Thesis, University of Idaho, Moscow, ID, 72 p.

[82] Catherine, S. and Rock, P. (2007) Organic Carbon, Organic Matter and Bulk Density Relationships in Boreal Forest Soils. Canadian Journal of Soil Science, 88, 315-325.

[83] Gomez, A., Powers, R.F., Singer, M.J. and Horwath, W.R. (2002) Soil Compaction Effects on Growth of Young Ponderosa Pine Following Litter Removal in California's Sierra Nevada. Soil Science Society of America Journal, 66, 1334-1343. http://dx.doi.org/10.2136/sssaj2002.1334

[84] Hesselbarth, W. and Vachowski, B. (2000) Trail Construction and Maintenance Notebook. 2000 Edition, 0023 2839P, USDA Forest Service, Missoula Technology and Development Center, Missoula.

[85] Lasanta, T., Garcia-Ruiz, J.M., Perez-Rontome, C. and Sancho-Marcen, C. (2000) Run-Off and Sediment Yield in a Semi-Arid Environment: The Effect of Land Management after Farm Land Abandonment. Catena, 38, 265-278. http://dx.doi.org/10.1016/S0341-8162(99)00079-X

[86] Jiang, P., Anderson, S.H., Kitchen, N.R., Sadler, E.J. and Sudduth, K.A. (2007) Landscape and Conservation Management Effects on Hydraulic Properties of a Claypan-Soil Toposequence. Soil Science Society of America Journal, 71, 803-811. http://dx.doi.org/10.2136/sssaj2006.0236

[87] Steffens, M., Kölbl, A., Totsche, K.U. and Kögel-Knabner, I. (2008) Grazing Effects on Soil Chemical and Physical Properties in a Semiarid Steppe of Inner Mongolia (P.R. China). Geoderma, 143, 63-72. http://dx.doi.org/10.1016/j.geoderma.2007.09.004

[88] Russell, J.R., Betteridge, K., Costall, D.A. and Mackay, A.D. (2001) Cattle Treading Effects on Sediment Loss and Water Infiltration. Journal of Range Management, 54, 184-190. http://dx.doi.org/10.2307/4003181

[89] Bouman, B.A.M., Nieuwenhyse, A. and Ibrahim, M. (1999) Pasture Degradation and Its Restoration by Legumes in Humid Tropical Costa Rica. Tropical Grasslands, 33, 142-165.

[90] Alados, L., Ahmed, E.L., Aich, A., Papanastasis, V.P., Ozbek, H., Navarro, T., Freitas, H., Vrahnakis, M., Larrosi, D. and Cabezudo, B. (2004) Change in Plant Spatial Patterns and Diversity along the Successional Gradient of Mediterranean Grazing Ecosystems. Ecological Modelling, 180, 523-535. http://dx.doi.org/10.1016/j.ecolmodel.2003.10.034 
Scientific Research Publishing (SCIRP) is one of the largest Open Access journal publishers. It is currently publishing more than 200 open access, online, peer-reviewed journals covering a wide range of academic disciplines. SCIRP serves the worldwide academic communities and contributes to the progress and application of science with its publication.

Other selected journals from SCIRP are listed as below. Submit your manuscript to us via either submit@scirp.org or Online Submission Portal.
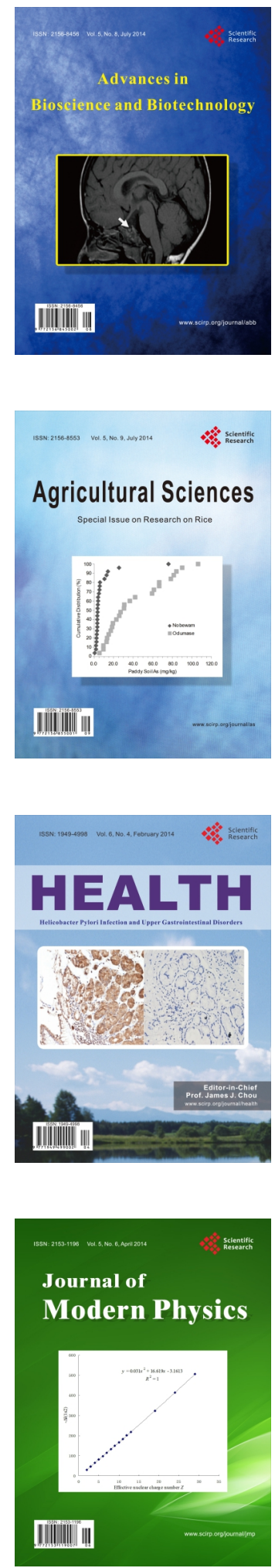
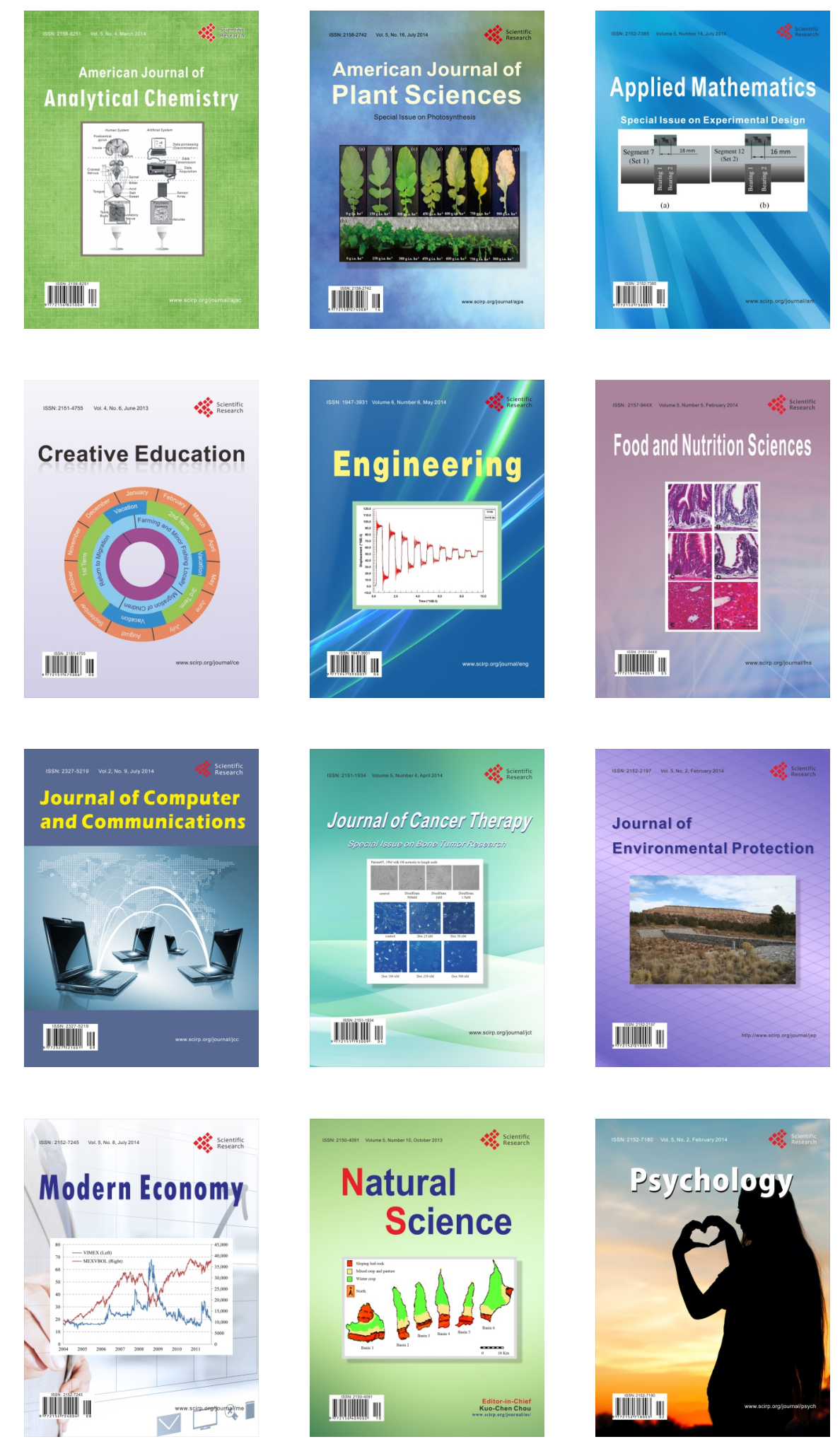